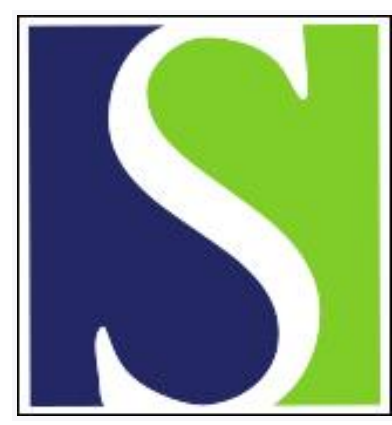

Scand J Work Environ Health 1987;13(5):412-416

https://doi.org/10.5271/sjweh.2019

Issue date: Oct 1987

Mortality in the Swedish glassworks industry.

by Wingren $G$, Axelson 0

Affiliation: Department of Occupational Medicine, University Hospital, Linkoping, Sweden.

The following article refers to this text: 1989;15(4):245-264

This article in PubMed: www.ncbi.nlm.nih.gov/pubmed/3433043 


\title{
Mortality in the Swedish glassworks industry
}

\author{
by Gun Wingren, BSc, Olav. Axelson, MD ${ }^{1}$
}

\begin{abstract}
WINGREN G, AXELSON O. Mortality in the Swedish glassworks industry. Scand $J$ Work Environ Health 13 (1987) 412-416. An earlier, relatively small case-referent study has shown an increased risk for glassworks employees to die from stomach cancer, lung cancer, and cardiovascular disorders. This observation suggested an extended study virtually covering the entire glass-producing industry of Sweden. This new study confirmed the earlier results and, furthermore, an excess risk for colon cancer was also identified. No deviation was found in the cancer mortality pattern for all men in the glass-producing area compared to the whole of Sweden. The grouping of glassworks employees according to type of metal consumption at the glassworks showed the excess risks of stomach cancer, colon cancer, and cardiovascular deaths to relate to glassworks with a high consumption of lead, arsenic, antimony, and manganese. However, the strong correlation of these various metal exposures did not permit any successful separation of the effects of the different metals. For cardiovascular mortality, as for cancer, the glassblowers especially suffered from increased risk. Their exposure might, to a great extent, be oral, involving the glassblower's pipe as a "vector" for the exposure to various metals.
\end{abstract}

Key terms: cardiovascular disease, colon cancer, heavy metals, lung cancer, stomach cancer.

Employment in glassworks means exposure to a mixture of chemicals, especially metals. In general, little information is available in the literature about the health hazards in this branch of industry. However, many of the chemicals used are known to cause human health hazards in various respects, eg, arsenic, lead, cadmium, nickel, chromium, and fluorine compounds.

In an earlier case-referent study (22) on glassworks employees from three parishes in the glass-producing area of southeast Sweden, we found an increased risk for cancer of the stomach and lung and also for deaths from cardiovascular disease. The largest glassworks included in that study produced mainly crystal glass and consumed large amounts of arsenic and lead. The excess risk for stomach cancer could be referred to glassblowers, whereas the risk for lung cancer mainly occurred among unspecified glassworkers and the risk for cardiovascular deaths was observed in both these groups.

This new case-referent study was undertaken for the ultimate assessment of the risk situation of Swedish glass workers and includes also the population of the three parishes as earlier studied. In other words, the study covers virtually the entire artistic glass industry of Sweden, including employees from a number of glassworks which have been closed down.

\section{Subjects and methods}

The registers of deaths and burials in the total of 11 parishes were used as the source of subjects, but a sepa-

\footnotetext{
1 Department of Occupational Medicine, University Hospital, 58185 Linköping, Sweden.
}

Reprint requests to: Ms G Wingren, Department of Occupational Medicine, University Hospital, S-581 85 Linköping, Sweden. rate analysis was also undertaken for the eight parishes not involved in the previous study. The material encompassed men in cancer productive ages only, taken as 45 years of age or more, thereby also somewhat allowing for an induction latency period. The causes of death were classified according to the eighth revision of the International Classification of Diseases (ICD 8) (17).

To obtain information on past and present exposure, a questionnaire was sent to 13 currently operating glassworks. It requested information about the present consumption of metals, as well as that of 25 years ago, namely, with regard to antimony, arsenic, cadmium, chromium, copper, lead, manganese, nickel, selenium, and zinc. This questionnaire was answered by seven of the glassworks.

The exposure was classified in the following three ways: (i) by regarding any glassworks employment, according to the titles given in the registers of deaths and burials, as exposure; (ii) by distinguishing between six different occupational categories, namely (a) glassblowers, (b) other foundry workers, (c) grinders, engravers and similar workers, (d) etchers, polishers, painters and similar workers, (e) controllers, packers and similar workers, and (f) unspecified glassworkers; and (iii) by creating exposure categories according to the pattern of metal consumption in the glassworks.

The unexposed reference category was taken as other men, 45 years of age or more in the same parishes and with titles other than those of glassworkers. These individuals were mainly farmers, forestry workers, and men in service activities in the rather rural area where the glassworks were located.

Multiple case-referent evaluations were carried out considering deaths from any type of cancer and from cardiovascular disease. Referents for these multiple comparisons were those individuals in the area who 
had died from nonmalignant diseases except cardiovascular ones.

To evaluate the general cancer mortality pattern in the glass-producing area, ie, for obtaining information about base-line mortality, the observed total number of cases in the 11 parishes were compared with expected numbers as calculated from the death rates of the whole of Sweden.

The information obtained from seven of the existing glassworks regarding the consumption of 10 different metals around 1960 was used for creating exposure groups according to metal consumption in the different glassworks as far as a natural distinction was possible in this respect. Thereby the subjects from the parishes with responding glassworks were divided into three categories as follows: (i) employees from parishes with glassworks consuming only lead, arsenic and antimony, (ii) employees from parishes with glassworks which, besides lead, antimony and arsenic, also consumed relatively large amounts of manganese and to some extent also cadmium, copper, chromium, nickel, selenium and zinc, and (iii) employees from parishes with glassworks with a high consumption of especially zinc, cadmium and selenium, in addition to lead, antimony and arsenic. Case-referent studies regarding the aforementioned causes of death, ie, various cancer forms and cardiovascular disease, were performed for each of these metal-consumption groups. Furthermore, the correlations between the different metals were calculated with the referents (noncancer and noncardiovascular deaths) representing the situation in the study base.

In the statistical analysis, the calculations of the odds ratios (OR) and test-based $90 \%$ confidence intervals
( $90 \% \mathrm{CI}$ ), which turned out to be the most informative, followed the principles of Mantel-Haenszel (13) and Miettinen $(14,15)$. The study design implies that the odds ratios are equal to incidence density ratios.

\section{Results}

The study covered the period 1950-1982 and a population of 5498 men, 887 of whom were identified as glassworks employees.

The "base-line" mortality in the glass-producing area with regard to total cancer, stomach cancer, colon cancer, and lung cancer agreed well with that of Sweden as a whole, except a significantly low occurrence of lung cancer with a standardized mortality odds ratio of 0.5 ( $90 \% \mathrm{CI} 0.4-0.7)$, as is typical for a rural population. In table 1, the case-referent evaluations are presented, taking all glassworks employees as the exposed group. A moderate but significantly increased odds ratio was observed for glassworkers with regard to total cancer (ICD 140-209), stomach cancer (ICD 151), colon cancer (ICD 153), lung cancer (ICD 162), and cardiovascular deaths (ICD 410-414 and 427429). Other cancer forms were also studied but no more indications of increased risks were found with regard to the total study population in the area.

A separation of the available occupational titles into the six aforementioned occupational categories made it possible to relate the excess risks for the various causes of death to more specific job tasks. The highest risks appeared among the glassblowers (table 2). For the group of unspecified glassworkers, significantly increased risks were seen for colon cancer and lung can-

Table 1. Case-referent data on men, 45 years of age or more, in 11 parishes in the glass-producing area during the period 1950-1982. The referents were subjects deceased from noncancer and noncardiovascular disorders. Exposure was taken as glassworks employment. (ICD = international Classification of Diseases)

\begin{tabular}{|c|c|c|c|c|c|c|}
\hline Age group & $\begin{array}{c}\text { Total } \\
\text { cancer } \\
(\text { ICD } 140-209)\end{array}$ & $\begin{array}{l}\text { Stomach } \\
\text { cancer } \\
\text { (ICD 151) }\end{array}$ & $\begin{array}{c}\text { Colon } \\
\text { cancer } \\
\text { (ICD 153) }\end{array}$ & $\begin{array}{l}\text { Lung } \\
\text { cancer } \\
\text { (ICD 162) }\end{array}$ & $\begin{array}{c}\text { Cardiovascular } \\
\text { deaths } \\
(1 C D 410-414+ \\
427-429)\end{array}$ & $\begin{array}{l}\text { Refer- } \\
\text { ents }\end{array}$ \\
\hline \multicolumn{7}{|l|}{$45-64$} \\
\hline $\begin{array}{l}\text { Exposed subjects } \\
\text { Unexposed subjects }\end{array}$ & $\begin{array}{r}57 \\
175\end{array}$ & $\begin{array}{l}11 \\
27\end{array}$ & $\begin{array}{r}5 \\
14\end{array}$ & $\begin{array}{r}6 \\
15\end{array}$ & $\begin{array}{r}57 \\
247\end{array}$ & $\begin{array}{r}81 \\
299\end{array}$ \\
\hline \multicolumn{7}{|l|}{$65-74$} \\
\hline $\begin{array}{l}\text { Exposed subjects } \\
\text { Unexposed subjects }\end{array}$ & $\begin{array}{r}63 \\
319\end{array}$ & $\begin{array}{l}19 \\
57\end{array}$ & $\begin{array}{r}3 \\
17\end{array}$ & $\begin{array}{r}7 \\
31\end{array}$ & $\begin{array}{l}116 \\
442\end{array}$ & $\begin{array}{r}88 \\
435\end{array}$ \\
\hline \multicolumn{7}{|l|}{$\geq 75$} \\
\hline $\begin{array}{l}\text { Exposed subjects } \\
\text { Unexposed subjects }\end{array}$ & $\begin{array}{r}82 \\
442\end{array}$ & $\begin{array}{l}14 \\
78\end{array}$ & $\begin{array}{l}10 \\
30\end{array}$ & $\begin{array}{r}8 \\
19\end{array}$ & $\begin{array}{l}174 \\
993\end{array}$ & $\begin{array}{r}169 \\
1259\end{array}$ \\
\hline \multicolumn{7}{|l|}{ Total } \\
\hline $\begin{array}{l}\text { Exposed subjects } \\
\text { Unexposed subjects }\end{array}$ & $\begin{array}{l}202 \\
936\end{array}$ & $\begin{array}{r}44 \\
162\end{array}$ & $\begin{array}{l}18 \\
61\end{array}$ & $\begin{array}{l}21 \\
65\end{array}$ & $\begin{array}{r}347 \\
1682\end{array}$ & $\begin{array}{r}339 \\
1993\end{array}$ \\
\hline $\begin{array}{l}\text { Crude odds ratio } \\
\text { Mantel-Haenszel chi square } \\
\text { Mantel-Haenszel odds ratio } \\
\text { with } 90 \% \text { confidence interval }\end{array}$ & $\begin{array}{c}1.3 \\
3.5 \\
1.2 \\
1.02-1.4\end{array}$ & $\begin{array}{c}1.6 \\
4.8 \\
1.5 \\
1.1-2.0\end{array}$ & $\begin{array}{c}1.7 \\
3.2 \\
1.6 \\
1.04-2.5\end{array}$ & $\begin{array}{c}1.9 \\
4.0 \\
1.7 \\
1.1-2.5\end{array}$ & $\begin{array}{c}1.2 \\
4.8 \\
1.2 \\
1.1-1.4\end{array}$ & \\
\hline
\end{tabular}


Table 2. Distribution of cancer cases, cardiovascular cases, and referents in different job categories for men, 45 years of age or more, who died during the period 1950-1982. The referents were subjects deceased from noncancer and noncardiovascular disorders. The age stratification underlying the analyses has been omitted. (ICD = International Classification of Diseases, $\mathrm{OR}=$ odds ratio, $90 \% \mathrm{Cl}=90 \%$ confidence interval)

\begin{tabular}{|c|c|c|c|c|c|c|c|c|c|c|c|c|c|}
\hline \multirow[t]{2}{*}{ Work categories } & \multirow[t]{2}{*}{ Referents } & \multicolumn{3}{|c|}{$\begin{array}{l}\text { Stomach cancers } \\
\text { (ICD 151) }\end{array}$} & \multicolumn{3}{|c|}{$\begin{array}{l}\text { Colon cancers } \\
\quad \text { (ICD 153) }\end{array}$} & \multicolumn{3}{|c|}{$\begin{array}{l}\text { Lung cancers } \\
\text { (ICD 162) }\end{array}$} & \multicolumn{3}{|c|}{$\begin{array}{c}\text { Cardiovascular deaths } \\
\text { (ICD } 410-414+ \\
427-429 \text { ) }\end{array}$} \\
\hline & & Number & OA & $90 \% \mathrm{Cl}$ & Number & OR & $90 \% \mathrm{Cl}$ & Number & OR & $90 \% \mathrm{Cl}$ & Number & OR & $90 \% \mathrm{Cl}$ \\
\hline Unexposed & 1993 & 162 & . & . & 61 & . & . & 65 & . & . & 1682 & . & . \\
\hline \multicolumn{14}{|l|}{ Exposed } \\
\hline Glassblowers & 53 & 11 & 2.6 & $1.5-4.4$ & 5 & 3.1 & $1.4-6.5$ & 4 & 2.3 & $1.0-5.5$ & 59 & 1.3 & $1.0-1.8$ \\
\hline $\begin{array}{l}\text { Other foundry } \\
\text { workers }\end{array}$ & 25 & 2 & . & - & 2 & . & . & 2 & . & - & 16 & 0.8 & $0.4-1.3$ \\
\hline $\begin{array}{l}\text { Grinders, engravers, } \\
\text { cutters, etc }\end{array}$ & 74 & 10 & 1.6 & $0.9-2.8$ & 1 & . & . & 2 & . & . & 78 & 1.2 & $0.9-1.6$ \\
\hline $\begin{array}{l}\text { Etchers, polishers, } \\
\text { painters, etc }\end{array}$ & 15 & 0 & . & $\cdot$ & 1 & . & . & 0. & . & . & 15 & 1.1 & $0.6-2.1$ \\
\hline $\begin{array}{l}\text { Controllers and } \\
\text { packers }\end{array}$ & 29 & 3 & 1.1 & $0.4-3.0$ & 0 & . & . & 2 & . & . & 22 & 0.9 & $0.5-1.4$ \\
\hline $\begin{array}{l}\text { Glassworkers } \\
\text { (not specified) }\end{array}$ & 143 & 18 & 1.4 & $0.9-2.2$ & 9 & 1.8 & $1.0-3.3$ & 11 & 1.9 & $1.1-3.4$ & 157 & 1.3 & $1.1-1.6$ \\
\hline
\end{tabular}

cer, as well as for cardiovascular deaths. No clear excess was seen for the other categories.

The case-referent evaluations of the associations between causes of death and type of metal consumption showed no significant increase of the overall risk for cancer or cardiovascular disease among glassworks employees from one parish with a glassworks consuming only lead, arsenic, and antimony. However, six out of eight colon cancer cases were found among unspecified glassworkers, giving an OR of 8.8 and a $90 \% \mathrm{CI}$ of $2.5-31.4$ for this work category. Glassworks employees in four parishes with glassworks with a high consumption of manganese and also lead, arsenic and antimony, and some other metals as earlier defined, had increased risks for stomach cancer (30 exposed cases, OR 1.7, $90 \%$ CI 1.2-2.6), colon cancer ( 8 exposed cases, OR 2.0, $90 \%$ CI 1.0-4.0), and cardiovascular deaths (193 exposed cases, OR 1.3, $90 \%$ CI 1.1-1.6). The glassworks employees in two parishes with glassworks consuming large amounts of zinc, cadmium, and selenium, besides lead, arsenic and antimony, had no significantly increased risks at all.

Further analyses indicated very strong correlations between the use of many of the metals, and, consequently, it was impossible to separate the effects of isolated metals, ie, to eliminate confounding from exposure to one metal when the effect of another was considered.

A special analysis was carried out for the eight new parishes, including one more year in the study period to increase somewhat the numbers, ie, for this analysis the study period was $1950-1983$. The results were as follows: stomach cancer (ICD 151) OR 1.2 and $90 \%$ CI 0.8-1.8, colon cancer (ICD 153) OR 2.1 and $90 \%$ CI 1.3-3.5, lung cancer (ICD 162) OR 1.4 and $90 \% \mathrm{CI} 0.8-2.5$, cancer of the urinary tract (ICD 188-189) OR 1.8 and $90 \%$ CI 1.0-3.1, and cardiovascular deaths (ICD 410-412 + 427-429) OR 1.1 and $90 \% \mathrm{CI} 0.9-1.3$.

\section{Discussion}

The chemical environment in a glassworks is very complex, and the workers are exposed to a mixture of chemicals, many of which are known to have adverse effects. Arsenic, nickel, and hexavalent chromium are recognized respiratory carcinogens $(2,5,6,10,12,20)$, and also antimony seems to have carcinogenic properties (18). An excess of cardiovascular disorders has been reported among individuals occupationally exposed to arsenic $(2,12)$. Cadmium has been suggested to cause cancer of the prostate $(9,11)$. Some lead salts have turned out to be carcinogenic in mice and rats (16), and recently published cohort studies have shown moderately but significantly elevated standardized mortality ratios for gastric and lung cancer among workers in a lead battery plant (3) and among smeltery workers (8). Hydrogen fluoride causes burns and has irritative effects on the respiratory system (19), factors which could also be of some relevance in this context. In earlier years the use of asbestos, with a potential risk for lung cancer, was common in the glassworks industry (21).

Long-term exposure to manganese can cause neurotoxic symptoms resembling Parkinson's disease (7), but no clear association with cancer has been reported. However, manganese has also been used in the form of manganate, which could imply oxidative capacity with free radical formation. Furthermore, manganese chloride has been shown to potentiate the development of lymphosarcoma in mice (4). Therefore, there is some biological plausibility that also manganese might have contributed to the cancer risks observed in this study, and a possible carcinogenic role of manganese would be worth further consideration.

The overall results of this study, which includes the data of our earlier study, confirm the findings of the earlier study, ie, that increased risks for stomach cancer, lung cancer, and cardiovascular deaths have occurred for men employed in the Swedish glassworks 
industry. In addition, an increased mortality from colon cancer has now been identified. The increased risk for cancer of the urinary tract occurred only for workers from two of the parishes, and there is no good explanation at present for this finding.

The increased risks for the different cancer types and for cardiovascular deaths as occurring mainly among glassblowers suggest a more extreme exposure situation for this category than for other glassworkers. The glassblower's direct oral contact with the working tool, the pipe, has made us interested in making metal analyses from inside the pipe. Preliminary results indicate that the concentrations of especially manganese, but also chromium, nickel, copper and to some extent lead and arsenic, can be considerable in slag from inside the pipe, probably resulting in some ingestion (to be published).

The other group with significantly increased death risks (except for stomach cancer) was the category of unspecified glassworkers. After comparing the occupational titles in the registers of deaths and burials for a sample of our study population with information on the same persons given by the local representatives of the labour union, $42 \%$ of the unspecified glassworkers could be referred to the group of "other foundry workers" and $17 \%$ to the group of glassblowers. Thus, the glassblowers' risks are likely to have been reflected in the results of the unspecified glassworkers, but other workers as well in this category may have been exposed in the most dusty environment of the foundry and under extreme heat stress. The latter aspect could be of some relevance in so far that increased consumption of contaminated drinking water might be involved and help explain the findings, ie, there is perhaps a possibility that waste disposals of metals in the neighborhood of the glassworks could have caused water contamination in the past, even if this proposition is somewhat hypothetical. No information on smoking habits, dietary habits, or other lifestyle factors could be accounted for in this study. Therefore, differences in these respects cannot be totally ruled out, but are less likely to have caused the rather strong effects that have been observed (1). The method of creating exposure groups according to the titles in the registers of death and burials could perhaps be somewhat imprecise, as only one title is given for each person and changes in occupation or work tasks over the years is not taken into account. However, glassworkers are considered to be a very stable occupational group, and this assumption is understandable as glassworkers in the artistic glass industry are very skilled and highly specialized in particular work tasks.

The specialization of glass production means different patterns of consumption, particularly for metals, in the various glassworks. It might be mentioned that (oxides of) cadmium, chromium, copper, manganese, nickel, zinc, and selenium are used in various glass batches as either decoloring or coloring agents, and antimony and arsenic are used as purifying agents to remove air bubbles from the glass. The association found in this study between colon cancer and, particularly, exposure to antimony, arsenic, and lead is relatively strong and therefore suggestive of a causal relationship. Besides the possibility of a connection between lung cancer and some of the metals, an effect from widespread asbestos exposure is also likely to be involved, but it was not specifically taken into account in this study. Asbestos has been used at many worksites in the glass industry of the past to protect the glasswares in transportation within the factories and as insulation material in the ovens.

Of particular interest for the future would be to study stomach cancer, as well as colon cancer, in suitable populations and with regard to lead, arsenic, antimony, and manganese exposure, especially in situations where ingestion may have occurred. Finally, the difficulty in this study to connect cancer risk with one specific metal or a few metals might also be a reflection of the possibility that a complex chemical environment as such causes cancer, an aspect worth consideration in further studies of metal carcinogenesis.

\section{Acknowledgments}

This study was supported by the Swedish Work Environment Fund.

We are grateful to Dr P Westerholm for submitting the proposal to study glassworkers.

\section{References}

1. Axelson O. Aspects on confounding in occupational health epidemiology. Scand J Work Environ Health 4 (1978) $85-89$.

2. Axelson O, Dahlgren E, Jansson C-D, Rehnlund SO. Arsenic exposure and mortality: A case-referent study from a Swedish copper smelter. Br J Ind Med 35 (1978) $8-15$.

3. Cooper WC, Wong O, Kheifets L. Mortality among employees of lead battery plants and lead production plants 1947-1980. Scand J Work Environ Health 11 (1985) $331-345$.

4. DiPaolo SA. The potentiation of lymphosarcoma in the mouse by manganous chloride. Fed Proc 23 (1964) 393.

5. Doll R, Morgan LG, Speizer FE. Cancers of the lung and nasal sinuses in nickel workers. Br J Cancer 24 (1970) $623-632$.

6. Enterline PE. Respiratory cancer among chromatome workers. J Occup Med 16 (1974) 523-526.

7. Eriksson $\mathrm{H}$, Heilbronn E. Changes in the redox state of neuroblastoma cells after manganese exposure. Arch Toxicol 54 (1983) 53-59.

8. Gerhardsson L, Lundström MG, Nordberg G, Wall S. Mortality and lead exposure: A retrospective cohort study of Swedish smelter workers. Br J Ind Med 43 (1986) $707-712$.

9. International Agency for Research on Cancer. Cadmium and cadmium compounds. Lyon 1976, pp 39-74. (Monographs evaluating the carcinogenic risk of chemicals to man, volume 11).

10. Jackson R, Grainge JW. Arsenic and cancer. Can Med 
Assoc J 113 (1975) 396-399.

11. Kjellström T, Friberg L, Rahnster B. Mortality and cancer morbidity among cadmium-exposed workers. Environ Health Perspect 28 (1979) 199-204.

12. Lee AM, Fraumeni JF Jr. Arsenic and respiratory cancer in man: An occupational study. J Natl Cancer Inst 42 (1969) 1045-1052.

13. Mantel M, Haenszel W. Statistical aspects of the analysis of data from retrospective studies of disease. J Natl Cancer Inst 22 (1959) 719-748.

14. Miettinen OS. Standardization of risk ratios. Am J Epidemiol 96 (1972) 383-388.

15. Miettinen OS. Estimability and estimation in casereferent studies. Am J Epidemiol 103 (1976) 226-235.

16. Moore MR, Meredith PA. The carcinogenicity of lead. Arch Toxicol 42 (1979) 87-94.

17. Swedish National Board of Health and Welfare. International statistical classification of diseases, injuries and causes of death (1965 revision adapted for indexing of hospital records and morbidity statistics) Liber distribution, Stockholm 1973.
18. National Institute for Occupational Safety and Health. Criteria for a recommended standard: Occupational exposure to antimony. US Department of Health, Education and Welfare, Washington, DC 1978. (Publication no $78-216$ ).

19. National Institute for Occupational Safety and Health. Criteria for a recommended standard: Occupational exposure to hydrogen fluoride. US Department of Health, Education and Welfare, Washington, DC 1976. (Publication no 76-143)

20. Prystowsky SD, Elfenbein GJ, Lamberg SI. Nasopharyngal carcinoma associated with long-term arsenic ingestion. Arch Dermatol 114 (1978) 602-603.

21. Selikoff IJ, Lee DHK. Asbestos and disease. Academic Press Inc, New York, NY 1978.

22. Wingren $G$, Axelson $\mathrm{O}$. Mortality pattern in a glass producing area in SE Sweden. Br J Ind Med 42 (1985) $411-414$.

Received for publication: 7 May 1987 